\title{
Tüketicilerin Covid19 (Korona) Virüsüyle Artan Stoklama İsteğinin Online Satın Alma Davranışına Etkisi
}

\author{
DOI: 10.26466/opus.716041 \\ * \\ Mehmet İnce* - Cansu Tor Kadıŏlu ** \\ * Prof. Dr. Tarsus Üniversitesi, Uygulamalı Bilimler Fakültesi, \\ E-Posta: mince@tarsus.edu.tr ORCID: 0000-0002-0574-0361 \\ ** Dr. Öğretim Üyesi Tarsus Üniversitesi, Uygulamalı Bilimler Fakültesi, \\ E-Posta: cansu@tarsus.edu.tr $\quad$ ORCID: 0000-0003-1663-9282
}

$\ddot{O} z$

Tüketim, bireylerin vazgeçilmez ihtiyaçlarındandır. Bireylerin satın alma davranışı birçok faktörden etkilenmektedir. Pandemik salgına bağlı olarak oluşan kriz ortamında tüketici davranışlarının da değişmesi muhtemel bir sonuçtur. Bu çalışma Covid19 Korona virüsünün 2020 yılı Mart ayında ülkemize yayılmasıyla, tüketici davranışlarında gözlenen değişimleri ortaya koymayı amaçlamaktadır. Araştırma online anket formu aracılığı ile 16-21 Mart 2020 tarihleri arasında, 369 kişinin katılımıyla yürütülmüştür. Türkiye'de salgının fazlasıyla yayıldı̆̆ı bir dönem geçiren ve kendilerini evlerinde karantinaya alan tüketicilerle yapılan görüşmelerden önemli bulgular elde edilmiştir. Araştırmanın sonuçları, salgin durumunda tüketicilerin daha fazla online satın aldiğııı ve bazı perakende ürünlere daha fazla rağbet ettiğini göstermiştir. Ayrıca AMOS programı ile yapılan yapısal eşitlik modellemesiyle, Korona virüs salgın sırasında, tüketicilerdeki stoklama eğiliminin online satın alma davranışın pozitif yönde etkilediği sonucuna ulaşılmıştır. Tüketicilerin salgın döneminde en sık alışveriş yaptığı online sitelerin sırasıyla Trendyol, Migros Sanal Market ve Hepsi Burada olduğu görülmüştür. Tüketicilerin çok miktarda satın aldıkları ürünler sırasıyla, çay/kahve, ev temizlik ürünleri, makarna ve kuru bakliyat olarak belirlenmiştir. Salgın riski ortadan kalktığında tüketicilerin sık sık el yıkamaya devam edecekleri, kalabalık ortamlara girmeyecekleri ve seyahat ederken temkinli olacakları ulaşılan bulgular arasındadır. Tüketicilerin karantina ve pandemik salgın sebebiyle yoğun olarak yaptıkları online satın alma davranışında ve stoklama eğiliminde demografik değişkenlere göre tespit edilen farklhlıklar bulunmaktadır. Araştırmanın doğal afet, salgın, kriz gibi zamanlarda tüketicideki olası değişimleri anlamak ve strateji belirlemek isteyen firmalara yol gösterici olması beklenmektedir.

Anahtar Kelimeler: tüketici davranışları, covid19, korona virüsü, çevrimiçi alışveriş, stoklamak, yapısal eşitlik modeli 


\title{
Effect of Consumers Increasing Stocking Request with the Covid19 (Corona) Virus on Online Purchasing Behavior
}

\begin{abstract}
Consumption is one of the indispensable needs of individuals. Individuals' buying behavior is influenced by many factors. It is possible to result that consumer behavior changes in a crisis environment due to pandemic outbreaks. This study aims to reveal the changes observed in consumer behavior with the spread of Covid19 Corona Virus to our country in March 2020. The research was carried out through the online questionnaire between 16-21 March 2020 with 369 participants. Significant findings were obtained from interviews with consumers who quarantined themselves at home in Turkey during the period in the spread of the pandemic. The results of the research have shown that in case of outbreak, consumers purchase more online and are more in demand for some retail products. In addition, with the structural equation modeling made with the AMOS program, it has been concluded that the stocking trend in consumers positively affects on online purchasing behavior during the Corona virus outbreak. It has been observed that the online sites where consumers shop most frequently during the pandemic period are Trendyol, Migros Sanal Market and Hepsi Burada, respectively. The products that consumers purchase in large quantities are determined as tea / coffee, household cleaning products, pasta and dried legumes, respectively. When the risk of pandemic disappears, the findings shows that consumers will "continue to wash hands frequently", will not enter crowded environments" and "will be cautious while traveling". There are differences determined according to demographic variables in online purchasing behavior and stocking tendency of consumers due to quarantine and pandemic outbreak. The research is expected to be a guide for companies which want to understand possible changes in the consumer behaviors and determine a strategy during times such as natural disasters, pandemics and crises.
\end{abstract}

Keywords: consumer behaviors, covid19, corona virus, online purchasing, stock up, structural equation model 


\section{Giriş}

Kendini devamlı değiştiren, geliştiren, her an istekleri farklılaşabilen karmaşık bir varlık olan insanın davranışlarının, niyetlerinin veya tutumlarının anlaşılması; pazarlama dünyası için önem taşımaktadır. Tüketici davranışları anlaşılmadan ya da tüketiciler tanınmadan istek ve ihtiyaçları belirlenemez ve onları motive eden değişkenler teşhis edilemez (Ünal ve Erciş, 2006, s.24). Pazarlamada rekabet üstünlüğ̈̈nün elde edilmesinin yollarından en önemlisi; tüketicinin dünyasın keşfedebilmek ve o dünyaya nüfus edebilmekten geçmektedir (Doğrul, 2012, s.328). Tüketicilerin satın alma davranışları birçok faktöre göre değişim gösterebilmektedir. Tüketici davranışını etkileyen kişisel faktörleri yaş ve yaşam döngüsü, gelir, ekonomik çevre, yaşam stili, kişilik ve benlik kavramı başlıkları altında inceleyebiliriz (Özden, 2007, s.27). Tüketicilerin yaşam stilini ve ekonomik çevresini doğrudan etkileyen bu salgının davranışlarını da etkileyeceğini söylemek mümkündür.

Günümüzde yaşanan Covid19 korona salgınıla tüketicilerin satın alma davranışı geleneksel satış alanlarından çevrimiçi mecralara doğru bir seyir göstermektedir. Tüketicilerin salgın anında en çok tercih ettikleri web sitelerden, salgın sonrası değişmesi beklenen davranışlarına kadar her aşamanın bilinmesinin, durumun yönetilmesini kolaylaştıracağı düşünülmektedir. Ekonominin genel yapısında olumsuzluk hisseden bir tüketici gelecek kaygisı taşıdığından fiyat artışı göstereceğine inandığı bir gida ürünü daha çok satın alarak stok yapmak isteyebilmektedir (Özden, 2007, s. 28). İngiltere, Amerika, Almanya ve Çin'de 2933 kişiyle yapılan bir başka araştırmada ise tüketicilerin yiyecek ve içecek harcamalarının Çin'de \%43, Almanya'da \%22, İngiltere'de \%27 ve Amerika'da \%27 arttığı belirlenmiştir (Statista, Tüketim Raporu, 2020). Bu araştırmada tüketicilerin online satın alma davranışlarının yanı sıra stoklama eğilimleri de araştırılmıştır. Covid19 korona virüs salgını etkisinde bulunan tüketicilerde yapılmış benzer bir çalışmaya henüz rastlanmamıştır. Yapılan bu çalışmanın alan yazına katkı sağlaması beklenmektedir.

Dünya sağlık örgütünün yaptı̆̆ı açıklamaya göre, Korona virüs salgını dünyada 200'den fazla ülkeye yayılmış durumdadır (WHO, Pandemi Raporu, 2020). Çin'den tüm dünyaya yayılan bu virüsün dünyada etkilediği kişi sayısı 850 bini geçerken, virüs 41bin'den fazla kişinin de ölümüne sebep olmuştur (Worldometers, 2020) Dünya sağlık örgütü 11 Mart 2020'de yaptığı 
açıklamada, söz konusu bu virüsü 'pandemik' olarak nitelemiştir (mckinsey.com, 2020). Korona virüsü salgını, Türkiye'de ve dünyada hayatın çeşitli alanlarında önemli etkiler yaratmaktadır. Birçok ülke bu virüsü kontrol altına almak için olağanüstü çaba göstermektedir. Kontrol altına alınması için büyük uğraşlar verilen ve önemli tedbirler alınan salgının, tüketicilerin tutum ve davranışlarında da değişiklik yaratması öngörülmektedir.

2019 yılında Çin'in Wuhan kentinde ortaya çıkan ve tüm dünyaya yayılan Covid19 Korona virüsünün etkileri birçok sektörde görülecektir. Türkiye ise ilk Korona vakası ile 09 Mart 2020' de karşılaşmış ve bir dizi önlemler almıştır. Virüsün bulaşmasını/yayılmasını engellemenin başlıca yolları olarak sosyal mesafe koyulması ve gerekmedikçe evden çıkılmaması olarak açıklanmışır (Sağlık Bakanlığı, 2020). Bu anlamda tüketiciler; alışveriş alanlarından uzaklaşmak, sosyal mecralarda daha fazla zaman geçirmek, uzun günler evlerinde vakit geçirmek durumunda kalmıştır. Yaşanan bu gelişmelerin tüketicilerin davranışlarını da değiştirebileceği düşünülmektedir.

Yapılan bazı araştırmalar tüketicilerin başlarına gelen kötü olaylarda, kıyafet, kitap, müzik, film tüketimlerinin devam ettiği bu tüketimin onlardaki stresi azalttı̆̆ ve acıyı hafiflettiği ortaya konmuştur (Kennett-Hensel, Sneath ve Lacey, 2012, s.57). Bazı araştırmalar ise yaşanan korkuyu hafifletmenin ve olası kötü etkilerden kaçınmanın yolu olarak, tüketicilerin hedonik (hazcı) alı̧verişe yöneldiğini ifade etmektedir (Babin, Darden ve Griffin, 1994; Silvera, Lavack ve Kropp, 2008).

Globalleşen dünyada riskler, mücadeleler, bilgiler ve hastalıklar çok hızlı şekilde yayılmaktadır (Jamal ve Budke, 2020, s.2). Perakendeciler içinse teknoloji, satış maliyetlerini düşürmek için, iş süreçleri geliştirebilmek için yarar sağlamaktadır. (Gülşen ve Özdemir, 2018, s.103). Böyle kriz zamanlarında değişen tüketici davranışlarını ön görebilmek, pazarlama stratejisi geliştirebilmek için büyük önem taşımaktadır. Yapılan bu çalışmada, öncelikle dünyanın mücadele ettiği ve Mart ayında ülkemizde ilk vakanın görüldüğü korona virüsü hakkında bilgilere yer verilmiştir. Daha sonra kriz anlarında değişen tüketici davranışları ile kavramsal çerçeve çizilmiştir, alan yazında incelenen araştırmalara değinilmiştir. Tüketicilerin salgın zamanında ortaya çkan stoklama istekleri, dünyada değişim gösteren perakende satış verileri ile desteklenmiştir.

Araştırmanın ikinci bölümünde tüketicilerin online satın alma davranışları ile ilgili bilgiler verilmiştir. Araştırmanın üçüncü bölümünde kullanılan 
araştırma yöntemi anlatılarak, örneklem, anket ifadeleri, veri toplama, amaç ve önem hakkında bilgi verilmiş ve araştırmanın hipotezlerine yer verilmiştir. Dördüncü bölümde ise yapılan istatiksel analizler ve analizlere ait değerleri içeren tablolar bulunmaktadır. Araştırmanın son bölümün sonuç ve önerilerden oluşmaktadır. Salgın dünyaya ve ülkemize yeni yayıldığı için bu konuda yapılmış bir çalışmaya daha rastlanmamıştır.

\section{Korona Virüsü Ve Etkileri}

Dünyaya yayılan Korona virüsün halkın sağlığını etkisi altına alması aslında yeni bir olay değildir. Korona virüsler, 21. yüzyılda keşfedilmiş ve 1960 yılından sonra insanlarda hafif solunum yolu hastalıklarına yol açtığı anlaşılmış, tüm dünyada yaygın şekilde görülebilen virüslerdir (İnal, 2016, s.37). 2000'li yılların başında SARS (Severe Acute Respiratory Syndrome) olarak patlak veren bu virüs, orta doğu solunum yetmezliği sendromu olarak adlandırılan MERS-Cov (Middle East Respiratory Syndrome) olarak da karşımıza çımıştır. 2002 yılında Guangdong'ta ortaya çıan SARS virüsü, 1 yıl içinde hızlı bir şekilde Çin'de ve Güney Doğu Asya bölgesinde yayılmıştır ve epidemik bir salgın olarak ilan edilmiştir. Yayıldığı otuz farklı ülkede 774 can kaybına sebep olan bu virüs, birçok ülkede yatırım ve ticaret anlaşmalarına zarar vermiştir (İnal, 2016, s.38).

31 Aralık 2019'da Çin'in yerel sağlık yetkileri tarafından açıklanan Covid19 virüsü ise (Nytime, 2020) Çin hükümetinin aldığı sıkı önlemlere rağmen dünyaya yayılmış ve pandemik bir salgın olarak ilan edilmiştir. Neredeyse 20 milyona yakın Wuhan'liya seyahat kısıtlaması getirilmiş (The Economist, 2020), birçok havayolu firması Çin'den uçuşlarını durdurmuştur (Bloomberg News, 2020). Çin'in 2002-2003 yılında geçirdiği SARS virüsünde kaybettiği vatandaşının sayısı 349 iken (WHO, Sars Raporu, 2020), Covid19 virüsü sebebiyle 6 Şubat 2020'de 600'den fazla kayıp yaşaması (New York Times, Live Update), bu virüsün tehlikesini ortaya koymaktadır. Genel olarak korona virüsü birçok hayvan türünden (fare, kuş çeşitleri, kedi, köpek, tavşan, domuz, yarasa, hindi vb.) bulaşabilen ve solunum yolunda hastalıklara yol açan bir virüstür (Su, Wong ve Shi, 2016, s.491).

Mart ayında Korona virüs ile ilgili vakaların dünyadaki durumu Tablo 1 'de sunulmuştur. 
Tablo 1. Dünyada korona virüsü etkileri

\begin{tabular}{llll}
\hline & Ülke Adi & Vaka Sayıs & Can Kaybi \\
\hline 1 & Amerika & 174,159 & 3,406 \\
2 & Italya & 105,792 & 12,428 \\
3 & Ispanya & 94,417 & 8,269 \\
4 & Çin & 82,278 & 3,309 \\
5 & Almanya & 68,180 & 682 \\
6 & Iran & 44,605 & 2,898 \\
7 & Fransa & 44,550 & 3,024 \\
8 & Ingiltere & 25,150 & 1,789 \\
9 & Isviçre & 16,186 & 395 \\
10 & Turkiye & 13,531 & 214 \\
11 & Belçika & 12,775 & 705 \\
12 & Hollanda & 12,595 & 1,039 \\
13 & Avusturya & 10,109 & 128 \\
14 & Güney Kore & 9,786 & 162 \\
15 & Kanada & 7,448 & 89 \\
16 & Portugal & 7,443 & 160 \\
17 & Israel & 4,831 & 20 \\
18 & Brazilya & 4,715 & 168 \\
19 & Norveç & 4,605 & 39 \\
\hline $\mathbf{2 0}$ & Avustralya & $\mathbf{4 , 5 5 7}$ & $\mathbf{1 9}$ \\
\hline
\end{tabular}

Kaynak: Johns Hopkins University, national public health agencies

Ülkemizde ise ilk Korona vakası 09 Mart 2020'de görülmüş olup Mart ayı 2020 itibariyle vaka sayısı ve can kaybı bakımından istatistiği maalesef artarak seyretmektedir. Türkiye Cumhuriyeti Sağlık Bakanlığı verilerine göre, ülkemizin güncel durumu Şekil 1'de görülmektedir.

\section{TÜRKIYE GÜNLÜK KORONAVIRÜS TABLOSU}

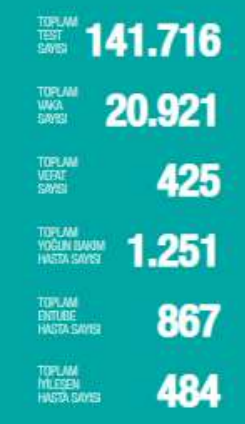

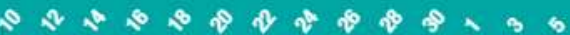

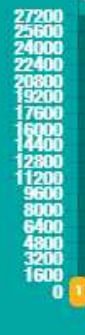

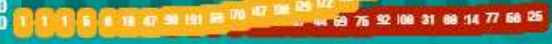

Vaka Saysi Velat Saysa

Şekil 1. Türkiye genel korona virüs durumu Kaynak: https://covid19.saglik.gov.tr/ 
Tablo incelendiğinde, Mart ayı itibariyle yapılan test sayısının 141 bini geçtiği, 20 binden fazla pozitif vaka olduğu ve 425 can kaybının yaşandığ görülmektedir. Yetkililer kamu ve özel kurumlarda birçok tedbir almış, eğitim öğretimin internet üzerinden yapılacağını açıklamış ve vatandaşları evde kalmaya davet etmiştir. Bu durumda şüphesiz ki evde kalıp daha çok online alışveriş yapacak olan bir tüketici grubu oluşacaktır. İhtiyaç duyulan ürünlerden, internette geçirilen zamana kadar birçok farklı konuda değişim yaşayan tüketicileri anlamak, olası bir kriz durumunda isteklerine en hızlı şekilde yanıt verebilmenin ilk adımıdır.

\section{Kriz Anlarında Değişen Tüketici Davranışları}

Kriz kelimesi sıklıkla tehdit veya sıkıntı kavramıyla birlikte kullanılmaktadır. Toplumun yaşamında görülen zor bir zamanı, buhran dönemini anlatmaktadır. Kriz, tehditlerin anlaşıldığı ve sorunu çözmeye ilişkin önlemler alınmadığı durumlarda, olumsuz bir sonuçla karşı karşıya kalınması durumunu ifade etmektedir (Dutton, 1986, s.503). Kriz, sosyal bilimler bölümünde genel olarak aniden ortaya çıkan kötü bir duruma doğru giden gelişme, sıkıntı ve buhran gibi sözcüklerle eş değer olarak kullanılmaktadır. Sosyal bilimler bağlamında kriz kavramına yönelik genel bir tanımda bulunmak zordur (Aktan ve Şen, 2001, s.1225). Krizler aynı zamanda çeşitli türlere ayrılmaktadır. Örneğin; bir sınıflandırmaya göre krizler ani ortaya çıkan krizler (doğal afet, terörist saldırıları vb.) ve yavaş ortaya çıkan krizler (mamul hataları, skandallar, rüşvet, yönetimsel hatalar vb.) olarak ele alınmaktadır (Arslan, 2009, s.182). Risklere göre sınıflandırıldığında ise krizler, kontrol edilebilir ve bilinen (ekonomik, siyasal, yönetimsel vb.), kontrol edilemez ve engellenemez (doğal afetler) ve bilinmeyen ve beklenmeyen (terör, şarbon vb.) olmak üzere üç gruba ayrılmıştır (Ulutaş, 2010, s.16). Yani krizler deprem, sel, yangın, meteor çarpması gibi doğal afetlerden kaynaklı olabileceği gibi, bir anda tüm dünyayı sarabilen bir bilgisayar virüsü gibi teknolojik bir afet kaynaklı ya da dünyayı saran bir mikropla salgın afeti olarak görülebilmektedir (Müftüoğlu, 2004, s. 7). Sözü edilen bu kriz anlarında tüketicilerin davranışlarını tahmin etmek, olası değişimleri öngörmek ve buna göre aksiyon almak pazarlamac1lar için önem arz etmektedir.

Alan yazın incelendiğinde; hava değişiminin alışveriş ve harcama davranışlarına etkileri (Murray, Di Muro, Finn ve Leszczyc, 2010), felaket yaşayan 
tüketicilerin satın alma artışı/azalışı ve algıladıkları riskler (Frank ve Schvaneveldt, 2016), terör saldırılarından sonra tüketicilerin seyahat niyetleri (Floyd, Gibson, Pennington ve Thapa, 2004), firtına/hortum/kasırga gibi doğal afetlerinden sonra tüketicilerin tepkileri ve duyarlılıkları (Baker, 2009; Guion, Scammon ve Borders, 2007; Kennett-Hensel vd., 2012) doğal afetlerle karşılaşan işletmelerin toparlanma planları (Guion vd., 2007; Runyan, 2006), domuz gribi salgınının İngiltere'deki global ekonomiye etkileri (Page, Song ve $\mathrm{Wu}, 2012$; Haque ve Haque, 2018), Eboola salgınının yarattığı kriz (Novelli, Burgess, Jones ve Ritchie, 2018), kuş gribi ve SARS mikrobunun yaşlı tüketiciler üzerinde etkileri (Lee ve Chen, 2011) ve pandemik salgınların turizme etkileri (Jamal ve Budke, 2020) ile alakalı araştırmalara rastlanmıştır. Elmore tarafinda 2017'de yapılan bir araştırmaya göre, Florida'da yaşanan Irma kasırgasından 1 hafta önce yapılan yakıt istasyonu harcamaları geçen yıla kıyasla \%63,2 artı̧ gösterirken, market alışverişleri \%41 artmıştır. ABD'de dayanıklı tüketim ürünlerinin online satın alımlarının önemli ölçüde yükseldiği görülmektedir. Pirinç, un, konserve sebzeler ve konserve bakliyatlar (+\% 433) satışları ocak ayına kıyasla mart ayında artış göstermiştir (Criteo, 2020). Vietnam'da yapılan bir araştırmaya göre, evde yiyecek stoklama eğilimi $\% 45$ artarken, online alışveriş aktivitelerinde \%25 artış tespit edilmiştir (Statista, Pandemi Sonrası Alışveriş Raporu, 2020). İngiltere'de kutu süt satışları geçen haftalara kıyasla 3,5 katı artarken, konserve meyve satışları 3 katı ve un satışları ise 6 kata kadar yükselmiştir (Criteo, 2020). İngiltere, Amerika, Almanya ve Çin' de 2933 kişiyle yapılan bir başka araştırmada ise tüketicilerin yiyecek ve içecek harcamalarının Çin'de \%43, Almanya' da \%22, İngiltere'de $\% 27$ ve Amerika'da \%27 oranında arttığı belirlenmiştir. (Statista, Bozulabilir Yiyecek Tüketim Raporu, 2020) Ipsos Hane Tüketim Paneli'nin ülkemizde yaptığı araştırmaya göre ise, okulların tatil olması ile birlikte makarna, bakliyat, un, kolonya, sirke, süt, çikolatalı ürünler, çöp torbası gibi ürünlerin satın alımında artış olmuştur (İpsos Hane Tüketim Paneli, 2020). Yine Amerika' da yapılan bir başka araştırmada, tüketimi en çok artan ürünler sırasıyla; süt ve süt ürünleri, konserve yiyecekler ve pirinç olmuştur (Statisca, Yiyecek Tüketim Raporu, 2020). Korona virüsü salgınının Türkiye'de etkili olmaya başladığı günlerde yapılan bir başka araştırmada ise, tüketicilerin ev dışında yemek yeme alışkanlıklarının da değiştiği görülmüsstür. Hazır yeme alışkanlığının azaldığı, eve siparişin ise arttı̆ Harcamas1, 2020). Bu anlamda kriz anında, (deprem, hortum, kasırga, virüs 
salgını vb.) bir perakende mağazanın ne kadar kolay ulaşılabilir olduğu büyük önem taşımaktadır (Larson ve Shin, 2018, s.3). Günümüzde kolay ulaşılabilirliği sağlayan en önemli araç ise şüphesiz ki çevrimiçi satış hizmeti sağlayan online alışveriş siteleri olarak görülmektedir.

\section{Tüketicilerin Salgın Zamanında Online Satın Alma Davranışı}

Günümüz toplumunda tüketiciler değişmeye başlamıştır. Tüketmek günümüzde elektronik hale gelmiştir. Yeni medya, akıllı mobil cihazlar ve tablet bilgisayarlar sayesinde tüketim alışkanlıklarının hızla online platformlara geçiş yapmıştır. Tüketiciler ürün ve hizmetlerin detaylı bilgilerine anında erişebilmekte ve ürünlere dokunmadan satın alma davranışını kolaylıkla gerçekleştirmektedir. Birçok tüketici internetten alışveriş yaparak zaman kazanmayı tercih etmektedir. Online alışveriş, kolay ve zaman kaybettirmediğinden, tüketiciler kısa sure zarfında birkaç tuşla fiziksel ya da geleneksel dükkanlarla uğraşmadan ürünleri satın alabilmelerini sağlamaktadır (Khan ve Rizvi, 2012, s.32).

Firmaların sağladığı online ortam tüketicilere günün her anında anlık ve acil alışverişlerini yapabilme imkânını vermektedir. Kullanıcılar ürün ve hizmet çeşitlerini bir arada görüntüleme ve her an her yerden istedikleri ürünleri satın alma imkânına sahip olmaktadır. Satın alınan ürünler geniş kitlelere hızla ulaştırılmaktadır. Böylece tüketiciler hem kolaylık hem de zamandan tasarruf sağlamakta ve dijital tüketimi daha fazla tercih etmektedir.

Literatürde ki çalışmalar, tüketicilerin internet üzerinden alışveriş yaparken davranışlarını etkileyen birçok faktör olduğunu göstermektedir Yapılan çalışmalar dikkate alındığında, tüketicilerin bir ürünü online satın almasına neden ya da engel olan esas ve en önemli faktörler; gizlilik, güvenlik ve güven, zaman kazanma, kullanım kolaylığı ve alışveriş keyfi olarak belirlenmiştir. (Udo, 2001; Liu ve Arnett, 2000; Harrison vd. 2002).

Salgının yaşandığı günlerde ise dünyada birçok ülkede karantina ilan edilmiştir. Ülkemizde ise kamu ve özel kurumlarda asgari personelle işlerin yürütülmesi, eğitimin uzaktan eğitim şekline çevrilmesi gibi önemli tedbirler alınarak vatandaşın evde kalması yönünde birçok karar alınmış ve düzenlemeler yapılmıştır. Alınan tedbirler kapsamında evde daha çok zaman geçirecek olan tüketiciler, online sipariş oluşturma, ihtiyaçlarını internet üzerinden eve teslim edilecek şekilde giderme yoluna gitmiştir. Online alışverişin arttığ 
bugünlerde, kullanımı kolay web sitesi olan, online sipariş sistemi olan ve iyi çalışan, akıllı telefonlara indirilebilir uygulamaları olan firmalar rakiplerinin bir adım ötesine geçmiştir. Araştırmada tüketicilere bu konu ile alakalı Korona virüsün ortaya çıması ile yaptıkları online alışverişlerde tercih ettikleri 3 online satış sitesi sorulmuştur. Verilen cevaplara ilişkin analiz tabloları bulgular bölümünde, konu ile ilgili sektöre faydalı olacak öneriler ise araştırmanın sonuç kısmında yer almaktadır.

\section{Yöntem}

Bu kısımda araştırmanın amacl, örneklemi, veri toplama yöntemi, araştırmanın hipotezleri ve araştırmada kullanılan analizler hakkında bilgi verilmektedir. Anket formunda yararlanılan ölçeklere ve kullanılan ifadelere de bu bölümde yer verilmiştir.

\section{Araştırmanın Amacı Ve Önemi}

Araştırmanın amacı, Covid19 salgını sebebiyle, tüketicilerin yaşadığı satın alma davranışındaki değişimlerin tespit edilmesidir. Dünya sağlık örgütünün ve diğer yetkililerin önerisi doğrultusunda mecbur kalmadıkça evden çıkmayan tüketicilerin internetten satın alma davranışlarında artış olacağı ön görülmüş ve bu yönde bir ölçek kullanılmıştır. Ayrıca tüketicilerin internetten satın alma davranışının demografik değişkenlere göre incelenmesi de hedeflenmiştir. Dünyaya yayılan bu pandemik salgının ülkemizde de ortaya çıkması ile tüketicilerin hangi ürünleri daha çok satın aldıkları ve bu salgın geçtikten değişecek olan bazı davranışlarının belirlenmesi önem arz etmektedir. Ayrıca bu araştırma tam da Covid19 virüsünün ülkemizde yayıldığı tarihlerde yapılması sebebiyle, tüketici davranışları ile ilişkilendirilerek yapılan ilk çalışmalardandır. Bu bakımdan orijinalite ve özgünlük taşımaktadır.

\section{Örneklem ve Veri Toplama}

Araştırmanın örneklemini; 2020 yılında tüm dünyanın yüzleştiği ve Mart ayı itibariyle Türkiye'de de yayılan Covid19 korona virüs salgını sürecini tecrübe eden tüketiciler oluşturmaktadır. Araştırmanın alan yazın kısmında ikincil 
veriler kullanılırken, araştırma kısmında anket aracılığg ile birincil veriler kullanılmıştır. Üç bölümden oluşan anket pandemik salgın sebebiyle yetkilerin sokağa çıkılmaması yönünde uyarılar sebebiyle için online anket haline getirilerek internet üzerinden toplanmıştır. Verilerin elektronik ortama aktarılmasına daha az vakit harcamak ve verileri işlerken ortaya çıkabilecek hataların sayısını en aza indirmek için anketin online ortamda toplanması söz konusudur (Uğraş, Reis ve Kartal, 2011, s.372). İnternet üzerinden oluşturulan anket az maliyetli, az zaman gerektiren ve daha az emek harcanması açısından daha avantajlidır (Karakoyun ve Kavak, 2008, s.130). Oluşturulan anket beş bölüm içermektedir. Öncelikle tüketicilerin Covid19 korona salgını sebebiyle online alışveriş yapıp yapmadıkları sorulmuştur. Daha sonra 2019 yılında Silva, Pınho, Soares, ve Sá tarafından kullanılan 3 ifadeli online satın alma davranışını ölçmek için kullanılan ölçek, ankette 'yapılan online satın alma davranışının Korona salgını sebebiyle olduğu' belirtilerek uyarlanıp kullanılmıştır. Anketin ikinci bölümü salgın anında tüketicilerin ürün stoklama eğilimini ölçmeye yönelik belirlenen 3 ifadeden oluşmaktadır. Bu ifadeler 2017 yılında King ve Devasagayam tarafından kullanılan 3 ifadeli mal teorisi ölçeğinden uyarlanarak kullanılmıştır. Anketin ilk iki bölümünde kullanılan online satın alma ve stoklama eğilimini ölçen ifadeler 5'li likert derecelemesine göre 1'den 5'e kesinlikle katılmıyorum .... kesinlikle katılıyorum, şeklinde cevaplanmıştır. Üçüncü kısımda, katılımcıların Korona virüsün ortaya çıkması ile yaptıkları online alışverişlerde tercih ettikleri 3 online satış sitesini yazmaları istenmiştir. Pandemik salgın riski ortadan kalktıktan sonra tüketicilerde değişebilecek davranışların tespiti için hazırlanan 'Korona virüs riski ortadan kalktığında hangi konularda temkinli olmaya devam edeceksiniz?' sorusuna 7 farklı cevap alternatifi eklendikten sonra sekizinci bir satır daha açılarak 'diğer' sekmesi eklenmiştir. Verilen cevapların katılımcılara uygun olmaması halinde 'diğger' sekmesine gelip dikkat edecekleri konuyu yazmaları istenmiştir.

Anketin dördüncü bölümünde tüketicilerin salgın ve karantina durumunda en çok tükettiği perakende ürünleri belirlemek hedeflenmiştir. Bu amaçla, 'Korona salgınıyla fazlaca satın aldığınız ürünleri düşünerek cevaplayınız' notu başa eklenmek suretiyle, salgın zamanında çok miktarda aldıkları ürün gruplarına dair 15 soru yöneltilmiştir. 'Listede olmayan eklemek istediğiniz ürünler varsa yazabilirsiniz' ifadesi ile katılımcıların, anket ifadeleri arasında yer almayan fakat salgın sırasında çok miktarda aldıkları bir ürün 
varsa eklemelerine olanak verilmiştir. Anketin son bölümünde katılımcıların demografik özelliklerini belirlemek için yaş, cinsiyet, gelir ve eğitim düzeylerine yönelik sorular yöneltilmiştir. Hazırlanan bu online anket formu, 16-21 Mart 2020 tarihleri arasında 369 tüketiciye ulaştırılmıştır. Örneklem sayısına karar verirken, anket içerisinde yer alan likert tipli soruların en az 10 katı sayıda örnekleme ulaşılması gerekmektedir (Büyüköztürk, 2005, s.142). Yap1lan araştırmada 22 adet likert tipli soru bulunduğu için, örneklem büyüklüğünün en az 220 kişi olması gerekmektedir. Bu bilgiler ışığında, 369 kişilik örneklem büyüklüğünün yeterli sayıyı sağladığı düşünülmektedir.

\section{Araştırmanın Modeli ve Hipotezleri}

CoVid19 virüsü ve online satın alma davranışı konularındaki kavramsal çerçeve ve bu konularla ilgili alan yazın çalışmaların incelenmesinden sonra, araştırma değişkenleri arasında ilişkisel bir yapı oluşturulmuştur. Araştırmanın modeli Şekil 2' de yer almaktadır.

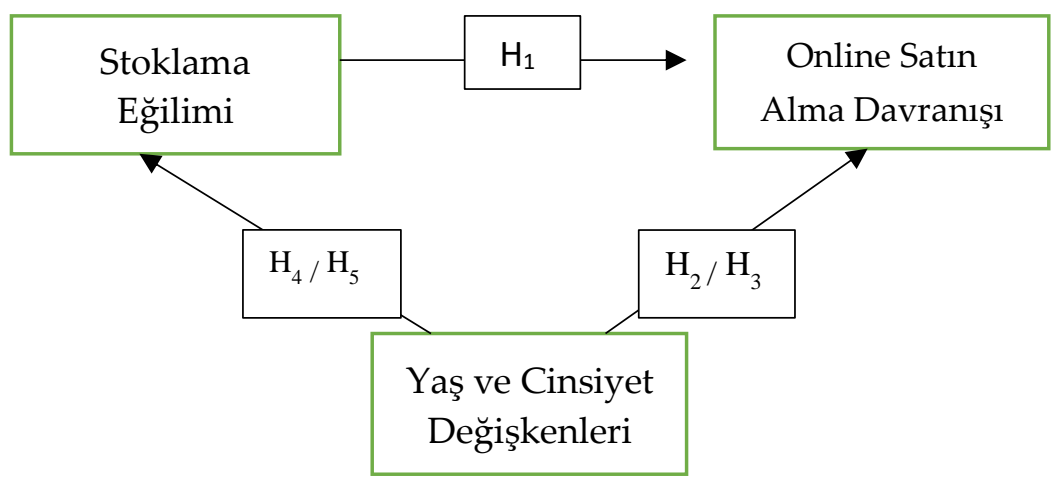

Şekil 2. Araştırmanın ilişsisel modeli

Model doğrultusunda kurulan hipotezler şu şekildedir;

- H1: Tüketicilerin yaşadığı Covid19 salgınında, ürün stoklama eğilimleri online satın alma davranışlarını pozitif yönde etkilemektedir.

- Hz: Tüketicilerin yaşadığı Covid19 salgınında online satın alma davranışları cinsiyete göre farklılık göstermektedir.

- $\quad \mathbf{H}_{3}$ : Tüketicilerin yaşadığı Covid19 salgınında online satın alma davranışları yaşlarına göre farklılık göstermektedir. 
- H: Tüketicilerin yaşadığ1 Covid19 salgınında ürün stoklama eğilimleri cinsiyete göre farklıllk göstermektedir.

- Hs: Tüketicilerin yaşadığ1 Covid19 salgınında ürün stoklama eğilimleri yaşlarına göre farklılık göstermektedir.

Yapılan araştırmada SPSS ve AMOS istatistik programları kullanılmıştır. Öncelikle araştırmaya katılan tüketicilerin, demografik değişkenlerine ilişkin sıklık analizi yapılmıştır. Daha sonra araştırmada kullanılan ölçeklerin güvenirlik skorları ve ifadelerin ortalama değerleri ölçülmüştür, ayrıca tek faktörlü yapıya sahip ölçeklerin doğrulayıcı faktör analizi de yapılmıştır. Farklılık hipotezlerinin testinde bağımsız $\mathrm{t}$ testi ve tek yön ANOVA testi kullanılmıştır. Kurulan ilk hipotezin testi için Yapısal Eşitlik Modellemesi-Yol Analizinden faydalanılmıştır.

\section{Bulgular}

Bu bölümde katılımclara ilişkin demografik bulgular, sıklık sorularına verilen cevaplara dair sonuçlar ve yorumları, ölçeklerin güvenilirlik değerleri ve yakınsak geçerliliği sonuçları, kurulan hipotez testlerinin sonuçlarına ait değerler ve yorumları yer almaktadır.

Tablo 2. Katılımcılarn demografik özelliklerine ait tablo

\begin{tabular}{|c|c|c|c|c|c|}
\hline Cinsiyeti & n & $\%$ & Yaş1 & n & $\%$ \\
\hline \multirow{3}{*}{$\begin{array}{l}\text { Erkek } \\
\text { Kadın }\end{array}$} & \multirow{3}{*}{$\begin{array}{l}167 \\
205\end{array}$} & \multirow{3}{*}{$\begin{array}{l}44,4 \\
55,6\end{array}$} & $18-31$ & 133 & 36,0 \\
\hline & & & $32-39$ & 142 & 38,5 \\
\hline & & & 40 ve üzeri & 94 & 25,5 \\
\hline Eğitim Durumu & $\mathbf{n}$ & $\%$ & Hane Geliri & $\mathbf{n}$ & $\%$ \\
\hline \multirow{7}{*}{$\begin{array}{l}\text { İlköğretim } \\
\text { Lise } \\
\text { Ön Lisans } \\
\text { Lisans } \\
\text { Yüksek Lisans } \\
\text { Doktora }\end{array}$} & \multirow{2}{*}{5} & \multirow{2}{*}{1,4} & 2000 TL ve altı & 17 & 4,6 \\
\hline & & & 2001-4000 TL & 84 & 22,8 \\
\hline & $\begin{array}{l}03 \\
49\end{array}$ & 17,0 & $4001-6000 \mathrm{TL}$ & 89 & 24,1 \\
\hline & 189 & $\begin{array}{l}10,3 \\
51,2\end{array}$ & $6001-8000 \mathrm{TL}$ & 69 & 18,7 \\
\hline & 55 & 149 & 8001-10000 TL & 58 & 15,7 \\
\hline & 6 & 16 & $10001-12000 \mathrm{TL}$ & 20 & 5,4 \\
\hline & 0 & 1,0 & 12001 TL ve üstü & 32 & 8,7 \\
\hline Toplam & 369 & 100 & Toplam & 369 & 100 \\
\hline
\end{tabular}

Tablo 2, ankete katılan tüketicilere ait yaş, cinsiyet, gelir ve eğitim durumu bilgilerini göstermektedir. Katılımcların 167'sinin erkek, 205'inin kadın; ağırlıklı olarak 32-39 yaş aralığında $(\% 38,5)$ olduğu; gelirlerinin en çok 4001 TL6000 TL arasında olduğu $(\% 24,1)$ ve yarıdan fazlasının lisans mezunu $(\% 51,2)$ 
olduğu anlaşılmaktadır. Katılımcılardan virüs salgını zamanında en çok alışveriş yaptıkları online siteleri yazmaları istenmiştir. Cevaplara ait sıklıklar Tablo 3'te yer almaktadır.

Tablo 3. Korona virüsü zamanında en sık alışveriş yapılan online sitelere ait tablo

\begin{tabular}{lll}
\hline Tercih Edilen Online Site & $\mathbf{n}$ & $\mathbf{\%}$ \\
\hline Trendyol & 99 & $26,83 \%$ \\
\hline Migros Sanal Market & 86 & $23,31 \%$ \\
\hline Hepsi Burada & 27 & $7,32 \%$ \\
\hline Gitti Gidiyor & 19 & $5,15 \%$ \\
\hline N11 & 16 & $4,34 \%$ \\
\hline Getir & 16 & $4,34 \%$ \\
\hline idefix & 8 & $2,17 \%$ \\
\hline Lcw & 6 & $1,63 \%$ \\
\hline Toplam & 369 & $100,00 \%$ \\
\hline
\end{tabular}

Yapılan bu araştırmaya katılan tüketicilerin sırasıyla Trendyol $(\% 26,8)$, Migros Sanal Market $(\% 23,31)$ ve Hepsi Burada $(\% 7,32)$ sitelerinden alışveriş yaptıkları görülmektedir. Dünyanın yaşadığı her epidemik ve pandemik salgında olduğu gibi salgın etkisini yitirecektir. Fakat tüketicilerde kalıcı davranış değişimleri olması mümkündür. Salgın sona erdiğinde temkinli olmaya devam edecekleri davranışlara ait ifadeler verilen cevapların sıklı̆̆ına ilişkin Tablo 4'te yer almaktadır.

Tablo 4. Salgın sonrası değişebilecek tüketici davranışlan

\begin{tabular}{lll}
\hline Salgın Sona Erse Bile Temkinli Olacağım Davranışlar & $\mathbf{n}$ & $\mathbf{\%}$ \\
\hline Temkinli olmaya gerek kalmadı̆̆ını düşünürüm & 16 & $2,11 \%$ \\
\hline Maske kullanmaya devam ederim & 17 & $2,24 \%$ \\
\hline Eldiven kullanmaya devam ederim & 22 & $2,90 \%$ \\
\hline Mecbur kalmadıkça evden çıkmamaya devam ederim & 70 & $9,23 \%$ \\
\hline Seyahat ederken temkinli olmaya devam ederim & 169 & $22,30 \%$ \\
\hline Kalabalık ortamlara girmemeye dikkat ederim & 214 & $28,23 \%$ \\
\hline Sik sık elimi yıkamaya devam ederim & 250 & $32,98 \%$ \\
\hline Toplam & 758 & $100,00 \%$ \\
\hline
\end{tabular}

Verilen 758 cevap incelendiğinde, salgın sonrası yapılacak davranışların; sik sik el yıkamaya devam etmek, kalabalık ortamlara girmemeye dikkat etmek, seyahat ederken temkinli olmaya devam etmek olduğu görülmektedir. Tüketicilerin salgın döneminde en sık satın aldığı ürünler de ankette sorulan 
sorular arasındadır. Verilen yanıtlara ait ortalama değerler ve standart hata değerlerine ilişkin bilgiler Tablo 5'te gösterilmektedir.

Tablo 5. Salgin döneminde çok miktarda alınan ürünlere dair tablo

\begin{tabular}{lllll}
\hline $\begin{array}{llll}\text { 'Çok miktarda ....... aldım' ifadesinde } \\
\text { yer alan ürünler }\end{array}$ & $\begin{array}{l}\text { Olumlu Yanıt } \\
\text { Veren Kişi Sayısı (n) }\end{array}$ & $\%$ & Ortalama & Standart Hata \\
\hline Çay/Kahve & 360 & 97,6 & 4,6802 &, 80465 \\
Konserve Yiyecek & 45 & 12,2 & 1,4688 &, 88449 \\
Ev Temizlik Ürünü & 346 & 93,7 & 4,5799 & 1,03982 \\
Süt & 127 & 34,5 & 2,1220 & 1,28908 \\
Et ve Et Ürünleri. & 104 & 28,2 & 1,9268 & 1,14330 \\
Kişisel Temizlik Ürünü & 112 & 30,3 & 2,0027 & 1,29064 \\
Meyve/Sebze. & 109 & 29,6 & 2,0081 & 1,21469 \\
Tuvalet Kağıdı & 122 & 33,1 & 2,0813 & 1,30171 \\
Kuru Bakliyat & 334 & 90,5 & 4,4146 & 1,19050 \\
Su & 137 & 37,1 & 2,1870 & 1,37337 \\
Hazır Çorba & 21 & 5,7 & 1,2873 &, 82678 \\
Un & 165 & 44,7 & 2,4743 & 1,42379 \\
Şeker & 88 & 23,8 & 1,8541 & 1,2598 \\
Makarna & 342 & 92,2 & 4,4878 & 1,10113 \\
Sivı Yağ & 96 & 26,1 & 1,9079 & 1,23894 \\
\hline
\end{tabular}

Tablo incelendiğinde yapılan salgın döneminde yürütülen araştırma sonucunda, tüketicilerin sırasıyla en çok çay/kahve $(\% 97,6)$, ev temizlik ürünü $(\% 93,7)$, makarna $(\% 92,2)$ ve kuru bakliyat $(\% 90,5)$ satın aldığı sonucuna ulaşılmıştır.

Araştırmada kullanılan ölçeklerin güvenirliklerini ölçmek için AMOS doğrulayıcı faktör analizi ve SPSS güvenirlik analizi testleri yapılmıştır. Ölçeklerin geçerlik ve güvenirliği çalışma sonuçlarının geçerli ve güvenilir kabul edilebilmesi için önem taşımaktadır (Demirali, 1995, s.126). Bu sebeple ölçekler AMOS programında doğrulayıcı faktör analizine de tabi tutulmuştur. Şekil 3'te online satın alma davranışına ait doğrulayıcı faktör ölçüm modeli bulunmaktadır. 


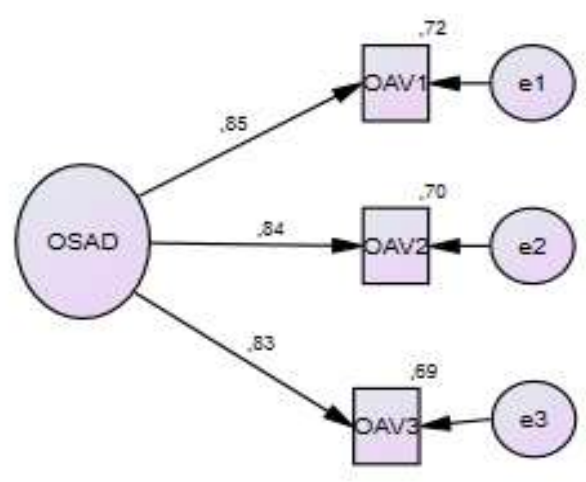

Şekil 3. Online satın alma davranışı ölçeğine ait doğrulayıcı faktör analizi

Kullanılan ölçeklerin yapı geçerliliğini test etmek amacıyla yapılan tek faktörlü doğrulayıc faktör analiziyle ifadelerin faktör yükünün yüksek olduğu görülmüştür. Modelin örneklemle iyi uyum gösterip göstermediğine dair değerler Tablo 6 da sunulmuştur.

Tablo 6. Online satın alma ölçeğine ait uyumluluk değerleri

\begin{tabular}{lllllll}
\hline & $\mathbf{X}^{2}$ & $\mathbf{d f}$ & $\mathbf{X}^{2} / \mathbf{d f}$ & GFI & CFI & RMSEA \\
\hline Uyum Değerleri &, 589 & 2 & 0,294 & 0,999 & 1,000 & 0,000 \\
\hline İyi Uyum Değerleri $^{*}$ & & & $\leq 3$ & $\geq 0,90$ & $\geq 0,97$ & $\leq 0,05$ \\
\hline Kabul Edilebilir Uyum Değerleri* & & & $\leq 4-5$ & $0,89-0,85$ & $\geq 0,95$ & $0,06-0,08$ \\
\hline
\end{tabular}

(Meydan ve Şeşen, 2011, s.37)

Uyum iyiliği değerleri incelendiğinde RMSEA değerinin mükemmel uyumu yakaladığı ve 3 'ün altında olan $\mathrm{X}^{2} / \mathrm{df}$ değerinin de iyi uyum gösterdiği görülmüştür. Değerler istenen aralıkta olduğundan, herhangi bir ifade silme işlemine veya modifikasyona gerek duyulmamıştır. Faktör yükleri ile hesaplana AVE ve CR değeri ile bilgiler ilerleyen kısımda ele alınmaktadır. Aynı şekilde stoklama isteği ölçeği de 3 ifade ile ölçülen tek faktörlü bir yapıdadır. Bu yapıya ait model Şekil 4'te yer almaktadır. 


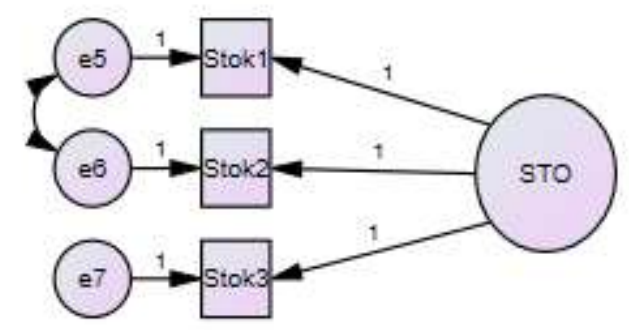

\section{Şekil 4. Stoklama ölçeğine ait doğrulayıcı faktör analizi sonuçları}

İfadelere ait faktör yüklerinin $0,79,0,82$ ve 0,86 olduğu görülmektedir. Uyum iyiliği tablosunda yer alan RMSEA, GIF, CIF ve $\mathrm{X}^{2} / \mathrm{df}$ değerlerinin istenen değer aralıklarında olması önem taşımaktadır. İstenen değer aralıkları ve yapıya ait modeli verilen ölçeğin uyum değerleri Tablo 7 'de gösterilmiştir.

Tablo 7. Stoklama ölçeğine ait uyumluluk değerleri

\begin{tabular}{lllllll}
\hline & $\mathbf{X}^{2}$ & $\mathbf{d f}$ & $\mathbf{X}^{2} / \mathbf{d f}$ & GFI & CFI & RMSEA \\
\hline Modifikasyon Sonrasi Uyum Değerleri & 2,582 & 1 & 0,108 & 0,995 & 0,997 & 0,066 \\
\hline Modifikasyon Öncesi Uyum Değerleri & 9,434 & 2 & 4,717 & 0,983 & 0,986 & 0,100 \\
\hline İyi Uyum Değerleri $^{*}$ & & & $\leq 3$ & $\geq 0,90$ & $\geq 0,97$ & $\leq 0,05$ \\
\hline Kabul Edilebilir Uyum Değerleri* $^{*}$ & & & $\leq 4-5$ & $0,89-0,85$ & $\geq 0,95$ & $0,06-0,08$ \\
\hline
\end{tabular}

(Meydan ve Şeşen, 2011, s.37)

Ölçeğe ait uyum iyiliği değerlerinin hepsinin beklenen aralıklarda çıtığı fakat RMSEA değerinin istenen aralığın üzerinde olduğu tespit edilmiştir. Analiz programının önerdiği modifikasyonlardan hareketle, 1 . ve 2. ifadeler arasında kovaryans bağlantısı kurulmuştur. Yapılan modifikasyonla, RMSEA değerinin 0,066'ya düştügü ve istenen uyumun yakalandığı görülmektedir.

Güvenilirlik, bir ölçme aracının tutarlı ölçüp ölçmediğini anlatmaktadır (Gürbüz ve Şahin, 2017, s.329). Güvenilirlik değerini ifade eden Cronbach's Alpha değerinin 0,70 ve üzerinde olduğu durumlarda, o ölçeğin dolayısıyla çalışmanın güvenilir olduğunu göstermektedir (Durmuş vd., 2013, s.89). Tablo 6 incelendiğinde, ankette kullanılan stoklama eğilimi ( 0,85 güvenirlik) ve online satın alma davranışı ( 0,87 güvenirlik) ölçeklerinin araştırma sonuçların yansıtmada güvenilir olduğu saptanmıştır. Tablo 7'de Cronbach Alpha 
değerlerinin yanı sıra, ifadelere ait faktör yüklerine ve yakınsak geçerliliği için hesaplanan AVE ve CR değerlerine de yer verilmiştir.

Tablo 8. Ölçüm modeline ait değerler tablosu

\begin{tabular}{llllll}
\hline Değişken & Kod & Faktör Yükü & AVE & CR & Cronbach Alfa \\
\hline Online Satın Alma Davranış1 & OAV1 & 0,85 & 0,706 & 0,878 & 0,877 \\
\cline { 2 - 3 } & OAV2 & 0,84 & & & \\
\cline { 2 - 3 } & OAV3 & 0,83 & & & \\
\hline Stoklama Eğilimi & STOK1 & 0,79 & 0,679 & 0,864 & 0,858 \\
\cline { 2 - 3 } & STOK2 & 0,82 & & & \\
\cline { 2 - 3 } & STOK3 & 0,86 & & & \\
\hline
\end{tabular}

Fornell ve Larcker' e göre (1981) yakınsak geçerliliğin sağlanabilmesi için ifadelere ait faktör yükü değerlerinin 0,50 'den az olmaması, ortalama açıklanan varyans değeri olan AVE'nin 0,50'ye eşit ya da daha fazla olması, birleşik güvenirliği ifade eden CR değerinin ise en az 0,70 ve daha fazla olması gerekmektedir. Tablo $8^{\prime}$ de verilen değerler incelendiğinde, faktör yüklerinin 0,790,86 arasında seyrettiği, AVE değerlerinin 0,67 ve 0,70 olarak hesaplandığı, $\mathrm{CR}$ değerinin 0,87 ve 0,86 olarak hesaplandığı görülmektedir. Bu değerlere göre yakınsak geçerliliğin de sağlandığı saptanmıştır. Tüketicilerdeki ürün stoklama eğiliminin online satın almaya etkisini ölçen yapısal bir model kurulmuştur. Araştırmanın ilk hipotezini test etmek için oluşturulan yapısal eşitlik modeli Şekil 5'te gösterilmiştir.

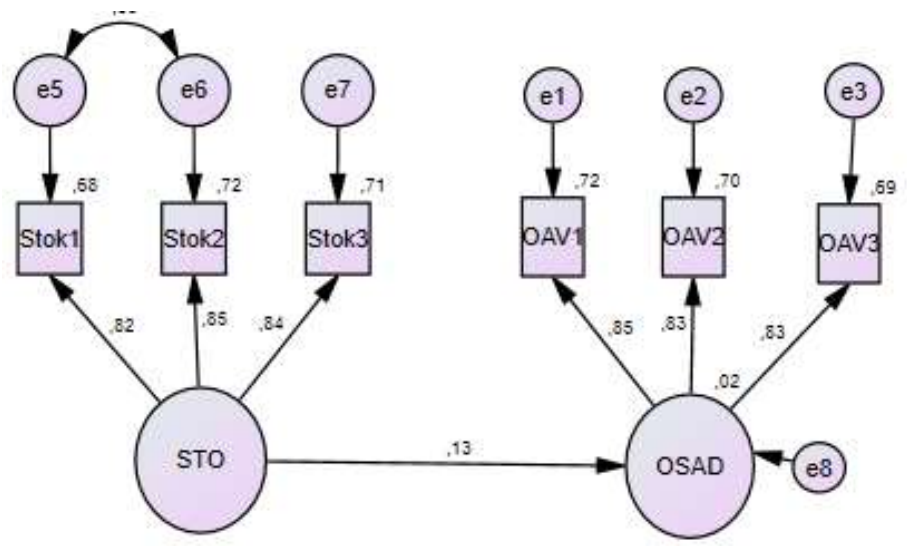

Şekil 5. Yapısal eşitlik modeli 
Şekil 5'te yer alan araştırma modelinin uyum iyiliği değerlerine Tablo 9'da yer verilmiştir. Tablodaki değerler incelendiğinde ortaya konan modelin uyum iyiliği değerlerinin oldukça iyi olduğu söylenebilmektedir.

Tablo 9. Modelin uyum iyiliği tablosu

\begin{tabular}{lllllll}
\hline & $\mathbf{X}^{\mathbf{2}}$ & $\mathbf{d f}$ & $\mathbf{X}^{2} / \mathbf{d f}$ & $\mathbf{G F I}$ & $\mathbf{C F I}$ & RMSEA \\
\hline Uyum Değerleri & 12,903 & 11 & 1,17 & 0,988 & 0,993 & 0,022 \\
\hline İyi Uyum Değerleri* $^{*}$ & & & $\leq 3$ & $\geq 0,90$ & $\geq 0,97$ & $\leq 0,05$ \\
\hline Kabul Edilebilir Uyum Değerleri & & & $\leq 4-5$ & $0,89-0,85$ & $\geq 0,95$ & $0,06-0,08$ \\
\hline
\end{tabular}

(Meydan ve Şeşen, 2011, s.37)

Tablo 9 'da yer alan RMSEA, GFI, CFI ve X²/df değerleri incelendiğinde modelin istenen uyum iyiliğini yakaladığını söylemek mümkündür. Değerler istenen aralıkta olduğundan, herhangi bir ifade silinmemiş ya da modifikasyona ihtiyaç duyulmamıştır. Kurulan yapısal eşitlik modelinin standardize edilmiş Beta katsayısı, standart hatası, kritik oranı, $p$ değeri ve $r^{2}$ değerlerine ilişkin sayılar Tablo 10'da yer almaktadır.

Tablo 10. Yapısal eşitlik modeli katsayıları

\begin{tabular}{lllllll}
\hline Değişkenler & & Stand. $\boldsymbol{\beta}$ & Standart Hata & Kritik Oran & $\mathbf{p}$ & $\mathbf{r}^{2}$ \\
\hline $\begin{array}{l}\text { Stoklama } \\
\text { Eğilimi }\end{array}$ & Online Satın & 0,112 & 0,052 & 2,169 & 0,02 & 0,13 \\
\hline
\end{tabular}

Tüketicilerdeki stoklama isteği, online satın alma davranışını $(\beta=0,117$; $\left.\mathrm{r}^{2}: 0,13, \mathrm{p}<0,05\right)$ etkilemektedir. Dolayısıyla araştırmanın $\mathrm{H1}$ numaralı hipotezi desteklenmiştir. Modele ait elde edilen squared multiple correlations $\left(\mathrm{r}^{2}\right)$ değerleri incelendiğinde de online satın alma davranışının \%13'ünün açıklandığı görülmektedir. Online satın alma davranışı ve ürün stoklama isteğinin demografik değişkenlere dair farklılıklarının tespiti için ise SPPS istatistik programinda t-test ve tek yön ANOVA analizlerine başvurulmuştur. Tablo 11 'de online satın alma davranışının cinsiyete göre farklılık yaratıp yaratmadığına dair bulgular paylaşılmıştır.

Tablo 11. Tüketicilerin online satın alma davranışının cinsiyete göre karşılaştıran t-testi sonuçları

\begin{tabular}{lllllll}
\hline Boyut & Gruplar & n & Ort. & S. Sapma & t & p \\
\hline OSAD & Kadın & 205 & 4,05 & 1,06 & 1,581 &, 088 \\
& Erkek & 164 & 3,86 & 1,13 & & \\
\hline
\end{tabular}


Tüketicilerin cinsiyetlerinin kadın ya da erkek olmasının, salgın döneminde yaptıkları online satın alma üzerinde anlamlı bir etkisi tespit edilememiştir ( $p=0,088>0,05)$. Cinsiyet fark etmeksizin ihtiyacını karşılamak isteyen her tüketicinin online alışveriş yaptığı bir dönem geçirildiği için bu sonucun ortaya çıtığı düşünülmektedir. Sonuç olarak $\mathrm{H}_{2}$ hipotezi reddedilmiştir. Tablo 12'de yaş gruplarına göre farklılık arayan analiz sonuçlarına yer verilmiştir.

Tablo 12. Tüketicilerin online satın alma davranışının yaş gruplarına göre karşılaştıran ANOVA tablosu

\begin{tabular}{|c|c|c|c|c|c|c|}
\hline Yaş Grupları & $\mathbf{n}$ & Ort. & S. Sapma & Ortalama Farkı & Sig. & p değeri \\
\hline \multirow[t]{2}{*}{$18-31$} & 133 & 4,19 & 0,917 & $(18-31)-(32-39)=0,178$ & ,365 & \multirow{6}{*}{000} \\
\hline & & & & $(18-31)-(40$ ve üzeri) $=0,601$ * &, 000 & \\
\hline \multirow[t]{2}{*}{$32-39$} & 142 & 4,01 & 1,048 & $(32-39)-(18-31)=-0,178$ & 365 & \\
\hline & & & & (32-39)-( 40 ve üzeri) $=, 421 *$ &, 010 & \\
\hline \multirow[t]{2}{*}{40 ve üzeri } & 94 & 3,59 & 1,311 & (40 ve üzeri)-(18-31) $=-0,601^{*}$ & ,000 & \\
\hline & & & & (40 ve üzeri)-( $32-39)=-, 421$ * & 010 & \\
\hline
\end{tabular}

Tablo 12, yaş gruplarına göre tüketicilerin online satın alma davranışın göstermektedir. En fazla online satın alan grubun 18-31 yaşları arasındaki tüketiciler olduğu anlaşılmaktadır. Ulaşılan $\mathrm{p}$ değerine bakıldığında ( $\mathrm{p}=$ $, 000<0,05$ ) online satın alma davranışının yaş grupları arasında anlamlı farklılaştığı anlaşılmaktadır. Kullanılan Tukey testi ile ortalama farklılıklarına ve sig. değerlerine bakıldığında bu farklılığın 18-31 yaş grubu arasındaki tüketiciler ile 40 ve üzeri yaş grubu tüketiciler arasında olduğu görülmektedir. Genç yaştaki tüketiciler yaşları büyük olan tüketicilere kıyasla daha fazla online satın almaktadır. Sonuç olarak $\mathrm{H}_{3}$ hipotezi kabul edilmiştir. Stoklama eğiliminin cinsiyete göre farklılaşıp farklılaşmadığını inceleyen t-test sonuçları Tablo 13'te yer almaktadır.

Tablo 13. Tüketicilerin stoklama eğilimlerinin cinsiyete göre karşılaştıran t-testi sonuçlarn

\begin{tabular}{lllllll}
\hline Boyut & Gruplar & $\mathbf{n}$ & Ort. & S. Sapma & $\mathbf{t}$ & $\mathbf{p}$ \\
\hline STOK & Kadın & 205 & 3,74 & 1,03 & 5,485 &, 000 \\
& Erkek & 164 & 3,07 & 1,33 & & \\
\hline
\end{tabular}

Tüketicilerin Covid19 virüs salgını döneminde stoklama eğilimleri cinsiyetlerine göre farklılık göstermektedir. $(\mathrm{p}<0,05)$. Bu sonuçlara göre $\mathrm{H}_{4}$ hipotezi kabul edilmiştir. Kadın tüketicilerin erkek tüketicilere göre daha fazla 
stok yapma eğiliminde olduğu görülmektedir. Yaş gruplarına göre bir farkl1lık arayan analize ait değerler Tablo $14^{\prime}$ te gösterilmiştir.

Tablo 14. Tüketicilerin stoklama eğilimlerinin yaş gruplarına göre karşılaştıran ANOVA sonuçları

\begin{tabular}{lllll}
\hline Yaş Grupları & $\mathbf{n}$ & Ort. & S. Sapma & p \\
\hline $18-31$ & 133 & 3,56 & 1,17 & \multirow{2}{*}{, 096} \\
\cline { 1 - 4 } $32-39$ & 142 & 3,47 & 1,21 \\
\hline 40 ve üzeri & 94 & 3,23 & 1,30 \\
\hline
\end{tabular}

Online satın alma konusunda yaş itibariyle bir farklılık tespit edilirken, stoklama eğiliminde böyle bir farklılaşma tespit edilememiştir $(\mathrm{p}=0,09>0,05)$. $\mathrm{Bu}$ sonuçlara göre $\mathrm{H}_{5}$ hipotezi reddedilmiştir. Tablo $15^{\prime}$ te araştırmanın modelinden yola çıkarak oluşturulan hipotezlerin kabul ve red durumlarına ilişkin genel bir sonuca yer verilmiştir.

Tablo 15. Araştırma hipotezlerinin genel sonuç tablosu

\begin{tabular}{ll}
\hline Araştırma Hipotezleri & Sonuç \\
\hline $\begin{array}{l}\text { H1:Tüketicilerin yaşadığı Covid19 salgınında, ürün stoklama eğilimleri online satın alma } \\
\text { davranışlarını pozitif yönde etkilemektedir. }\end{array}$ & Kabul \\
\hline $\begin{array}{l}\text { H2:Tüketicilerin yaşadığı Covid19 salgınında online satın alma davranışları cinsiyete göre } \\
\text { farklılık göstermektedir. }\end{array}$ & Red \\
\hline $\begin{array}{l}\text { H3: Tüketicilerin yaşadığı Covid19 salgınında online satın alma davranışları yaşlarına göre } \\
\text { farklılık göstermektedir }\end{array}$ & Kabul \\
\hline $\begin{array}{l}\text { H4: Tüketicilerin yaşadığı Covid19 salgınında ürün stoklama eğilimleri cinsiyete göre fark- } \\
\text { llık göstermektedir }\end{array}$ & Kabul \\
\hline $\begin{array}{l}\text { H5: Tüketicilerin yaşadığı Covid19 salgınında ürün stoklama eğilimleri yaşlarına göre fark- } \\
\text { llık göstermektedir }\end{array}$ & Red \\
\hline
\end{tabular}

\section{Tartışma ve Sonuç}

Araştırmanın bu bölümünde ulaşılan bulgular ve yapılan analizler ışığında elde edilen sonuçlara yer verilmiş ve genel bir değerlendirme yapılmıştır. Elde edilen sonuçlar alanyazındaki diğer çalışmaların sonuçlarıyla karşılaştırılarak değerlendirilmiştir. Salgın döneminde tüketici davranışlarını anlamayı hedefleyen sektör çalışanlarına ve bu konu ile alakalı çalışma yapmayı düşünen araştırmacılara bir takım önerilere yer verilmiştir.

\section{Genel Değerlendirmeler}

İşletmeler yoğun rekabet ortamında uzun dönemde ayakta kalabilmeleri için çağdaş pazarlama anlayışının gerektirdiği müşteri odaklı faaliyetlerdebulunmalıdır. Bunlardan bir tanesi de online kanallarda ulaşılabilir olmaktır. 
Çünkü salgın, afet gibi zamanlarda evinde kalması gereken tüketiciler, kolaylıkla online alışveriş yapabilmektedir. Korona virüs salgınından korunmak için mecbur kalmadıkça evlerinden çıkmayan tüketiciler, hayatlarını devam ettirmek için birçok farklı kategoride üründen çokça satın almıştır. Araştırmanın sonuçlarına göre Türkiye'de salgın dönemindeki tüketicilerin sırasıyla en çok çay/kahve, ev temizlik ürünü, makarna ve kuru bakliyat satın aldığı sonucuna ulaşılmıştır. Araştırmada elde edilen bulgulara göre; salgın döneminde tüketicilerdeki stoklama eğilimi, online satın alma davranışlarını pozitif yönde etkilemektedir.

Alan yazında online satın almaya etkisi olan; faydacı ve hazcı motivasyonlar (Saygıll, 2014), tüketici yorumları (Erdil, 2014), dijital pazarlama çalışmaları (Ekinci, 2019), web site tasarımı (Aksoy, 2019) gibi değişkenleri ele alan çalışmalara rastlanmıştır. Ayrıca, tüketicilerin bir felaket yaşaması durumunda mağaza içi ürün kullanılabilirliğinin azalttıklarına yani fazla satın alarak stoklarına dair çalışmalar da mevcuttur (Cavallo, Cavallo ve Rigobon, 2014; Hu, Gurnani ve Wang, 2013; Kleindorfer ve Saad 2005). Ancak stok yapma eğiliminin online satın almaya etkisini inceleyen bir araştırmaya rastlanmamıştır.

Salgın döneminde tüketicilerin stoklama eğilimlerine bakıldığında ise kadınların erkeklere kıyasla daha fazla stok eğiliminde olduğu, tüketicilerin yaşının ise bu konuda bir fark yaratmadığı ortaya konmuştur. Ayrıca, cinsiyetin online satın alma davranışı üzerinde bir fark yaratmadığı görülürken, genç tüketicilerin (18-31 yaş), daha yaşlı tüketicilere kıyasla daha fazla online satın alma gerçekleştirdiği bulgusuna ulaşılmıştır. Ulaşılan bu sonuçlar, internet alışverişini tercih eden tüketicilerin genç yaştaki tüketiciler olduğunu ifade eden diğer çalışmalarla (Swinyard ve Smith, 2003; Özgüven, 2011; İzgi ve Şahin, 2013) benzerlik göstermektedir.

\section{Sektörel Öneriler}

Doğal afetler, perakendeciler bir strateji hazırlayana dek, yönetimin kontrolü altında değildir (Guion vd., 2007; Runyan 2006). Yaşanan korona salgını, tüm ülkeyi ve ekonomiyi olumsuz etkilese de firmaların bu krizden kendilerine çıkarabilecekleri birçok ders bulunmaktadır. Bunların başında firmaların teknolojik ve dijital eksikliklerinin tespiti gelmektedir. Çok sayıda firma, bilgilendirici dokunmatik noktalar, dokunmatik ekranlarla donatılmış interaktif 
ekranlar, dijital tabela ve cep telefonları için uygulamalar gibi Radyo Frekans Kimliği (RFID) sistemleri ile donatılmış self servis teknolojileri gibi akıllı perakendecilik uygulamalarını kullanmaya başlamıştır (Pantano ve Timmermans, 2014, s.102). Teknolojiye dayalı uygulamalarda daha çok tüketiciye kolay şekilde erişmeye çalışmak sağlam bir adım olarak görülmektedir. Ayrıca yapay zeka ve dijital pazarlama uygulamalarına daha fazla yatırım yapılması önerilmektedir.

Salgın riski tamamen ortadan kalksa dahi, kalıcı olarak değişecek tüketici davranışlarından söz edilebilir. Tüketiciler, kalabalık ortamlara girmemeye, mecbur kalmadıkça evden çıkmamaya dikkat edeceklerini belirtmişlerdir. Bu yanitlardan hareketle, temizlik ürünlerinde; 'extra koruyucu, arttırılmış hijyen, arındırıcı, dezenfekte edici' ifadelerinin vurgulanması önerilebilir. Tüketicilerin salgın etkisini yitirse bile dikkat edeceği unsurlardan biri de kalabalık ortamlardan uzak duracaklarıdır. Sosyal mesafeye dikkat eden, mağaza/restoran/satış alanında üst düzey hijyen kurallarına dikkat eden ve bunu tüketiciye gösterebilen işletmelerin salgın sonrası rakiplerinden bir adım önde olacağı ön görülmektedir.

Tüketicilerin bir süre daha online alışverişle ihtiyaçlarını karşılayacağı, sosyal ortamlara girmekten kaçınacağı çalışma bulgularında ortaya konmuştur. Ohalde, firmalara sosyal medya pazarlamalarına özel bir zaman ve bütçe ayırmaları önerilebilir. Salgın anında yürütülen ve duyurulan sosyal sorumluluk kampanyaları da marka imajlarına katkıda bulunacak faaliyetler olacağ1 düşünülmektedir.

Yapılan araştırmalar incelendiğinde ve bu araştırmanın sonuçları göz önünde bulundurulduğunda, birçok tüketicinin uzun vadede bozulmayacak ürünlere (un, bakliyat, makarna vb.) ve sağladığı fonksiyonel faydası fazla olan ürünlere (ton balığı, kuru et, proteini yüksek konserve gıdalar vb.) rağbet ettiği görülmüştür. O halde firmalara, pazarladıkları ürünlerin, protein ve mineral içeriğini artırmaları, bu değişimi tüketicilerine duyurarak markalarını sağlıklı ve fonksiyonel faydası yüksek bir marka olarak konumlandırmaları tavsiye edilebilir. Perakende ürünler için dayanıklı ambalaj tasarımı yapmak, ürünlerin kullanım süresini uzatmakta öneriler arasında sayılabilir.

Alan yazında ve uygulamada kullanılan teknolojinin, akıllı telefonların, sosyal medyanın gücünün çoğunlukla $Y$ ve $Z$ kuşağı tüketicilerle ilişkilendirildiği bilinmektedir. Ancak yaşanan bu salgınla, online platformları, indiri- 
lebilir market uygulamalarını kullanmak zorunda olan X ve BB kuşağı tüketicilerle karşı karşıya kalınmıştır. Şöyle ki; Türkiye'de 21 Mart 2020 tarihi itibariyle, 65 yaş ve üzeri kişilerin ve kronik rahatsızlığı olan kişilerin sokağa çıkması yasaklanmıştır (İçişleri Bakanlığı, 2020). Dünyanın birçok yerinde de yaşlı tüketiciler uzun süre evlerinde karantinada kalmışlardır. Pazarlama firmalarının daha kolay ara yüzler geliştirerek yaşlı tüketicilerin de kolaylıkla çevrimiçi alışveriş yapabilmesini sağlayacak uygulamalar üretmesi öneriler arasındadır.

\section{Gelecekte Yapılacak Çalışmalara Öneriler}

Korona salgınıyla fazlaca satın aldığınız ürünleri düşünerek cevaplayınız uyarısı ile tüketicilerin çok miktarda satın aldığı düşünülen 15 ürün belirlenerek tasarlanan soruda, 'diğer' sekmesi de eklenerek katılımciların farklı bir ürün grubu eklemesine olanak verilmiştir. Alınan yantlar incelendiğinde, 'çok miktarda bebek bezi/mama aldım/stokladım' ifadeleriyle sıklıkla karşılaşılmıştır. Elde edilen bu bulgu, çocuklu tüketicilerin salgın dönemindeki davranışının ayrıca incelenmesi gerektiğini göstermektedir. Buna göre ileride yapılacak araştırmalarda demografik değişkenler bölümünde tüketicilerin medeni durumu, çocuk sahibi olup olmaması ya da kaç çocuk sahibi olduğu ile ilgili sorular eklenerek bu yönde hipotezler kurulması da önerilebilir. Tüketicilerin Covid19 virüsü döneminde sosyal mecralarda geçirdiği zamanın arttığ1 düşünüldüğünde, dijital tüketimleri ile alakalı araştırmalar yapılabilir. 


\title{
EXTENDED ABSTRACT
}

\section{Effect of Consumers Increasing Stocking Request with the Covid19 (Corona) Virus on Online Purchasing Behavior}

\author{
Mehmet İnce - Cansu Tor Kadığlu \\ Tarsus University
}

Understanding the behavior, intentions or attitudes of the human being, which is a complex entity that constantly changes, develops itself and can change its demands at any time, is important for the marketing world. The demands and needs cannot be determined and the variables that motivate them cannot be identified without understanding consumer behavior or recognizing consumers. Purchasing behavior of consumers can vary according to many factors. We can examine the personal factors that affect consumer behavior under the headings of age and life cycle, income, economic environment, lifestyle, personality and self. We can say that the corona epidemic will also affect the behavior of consumers, which directly affects the lifestyle and economic environment.

With today's Covid19 corona epidemic, the buying behavior of consumers is moving from traditional sales areas to online channels. Knowing every stage from the websites that consumers prefer most during the epidemic to their expected behaviors after the epidemic will make it easier to manage the situation.

According to the statement of the world health organization, the Corona virus outbreak has spread to more than 200 countries around the world. While the number of people affected by this virus spread from China to all over the world exceeds 850 thousand, the virus caused the death of more than 41 thousand people. The world health organization described this virus as 'pandemic' in its statement on 11 March 2020. In this sense, consumers; have to stay away from shopping areas, to spend more time in social media, long days had to spend time at home.

It is thought that these developments may also change the behavior of consumers. Some studies have shown that consumption of clothes, books, music 
and movies continues in bad events that occur to consumers, and this consumption reduces stress and relieves pain (Kennett-Hensel, Sneath and Lacey, 2012, p.57). Some research states that consumers tend to hedonic (hedonic) shopping as a way to alleviate the fear and avoid possible bad effects. (Babin, Darden and Griffin, 1994; Silvera, Lavack and Kropp, 2008).

In this study, information was given about the corona virus, in which the world struggled and the first case was seen in our country in March. In our country, the first Corona case was seen on March 9, 2020, and as of March 2020, the statistics are unfortunately increasing in terms of number of cases and loss of life.It is seen that the number of tests carried out as of March has exceeded 141 thousand, there are more than 20 thousand positive cases and 425 loss of life.

When the literature is examined; effects of weather change on shopping and spending behavior (Murray, Di Muro, Finn and Leszczyc, 2010), purchases increase / decrease and perceived risks of disaster consumers (Frank and Schvaneveldt, 2016), travel intentions of consumers after terrorist attacks (Floyd, Gibson, Pennington and Thapa, 2004), responses and sensitivities of consumers after natural disasters such as storm / tornado / hurricane (Baker, 2009; Guion, Scammon and Borders, 2007; Kennett-Hensel et al., 2012) recovery plans of businesses facing natural disasters (Guion et al. ., 2007; Runyan, 2006), the effects of swine flu outbreak on the global economy in the UK (Page, Song and $\mathrm{Wu}, 2012 ;$ Haque and Haque, 2018), the crisis caused by the Eboola outbreak (Novelli, Burgess, Jones, and Ritchie, 2018), research on the effects of avian influenza and SARS microbe on elderly consumers (Lee and Chen, 2011) and the effects of pandemic outbreaks on tourism (Jamal and Budke, 2020) research has been found.

In the days of the epidemic, quarantine was declared in many countries in the world. In our country, many decisions were taken and arrangements were made for the citizens to stay at home by taking important measures such as carrying out the works with minimum personnel in public and private institutions, and turning education into distance education. Consumers, who will spend more time at home as part of the measures taken, went on to create online orders and to meet their needs to be delivered to the home via the internet.

The aim of the research is to determine the changes in the purchasing behavior that consumers experience due to the Covid19 epidemic. Unless 
obliged by the recommendation of the World Health Organization and other officials, it is predicted that consumers who do not leave the house will have an increase in online buying behavior. In addition, it is aimed to examine the online buying behavior of consumers according to demographic variables.With the emergence of this pandemic epidemic spread throughout the world, it is important to determine which products consumers buy more and some behaviors that will change after this epidemic has passed.In addition, this research is one of the first studies carried out in association with consumer behavior, since the Covid19 virus was carried out at the time it spread in our country. In this regard, it has originality.

The research was carried out through the online questionnaire between 16-21 March 2020 with 369 participants. After examining the conceptual framework on CoVid19 virus and online purchasing behavior and the literature studies related to these issues, a relational structure was established between research variables. The model of the research is given in Figure 2.

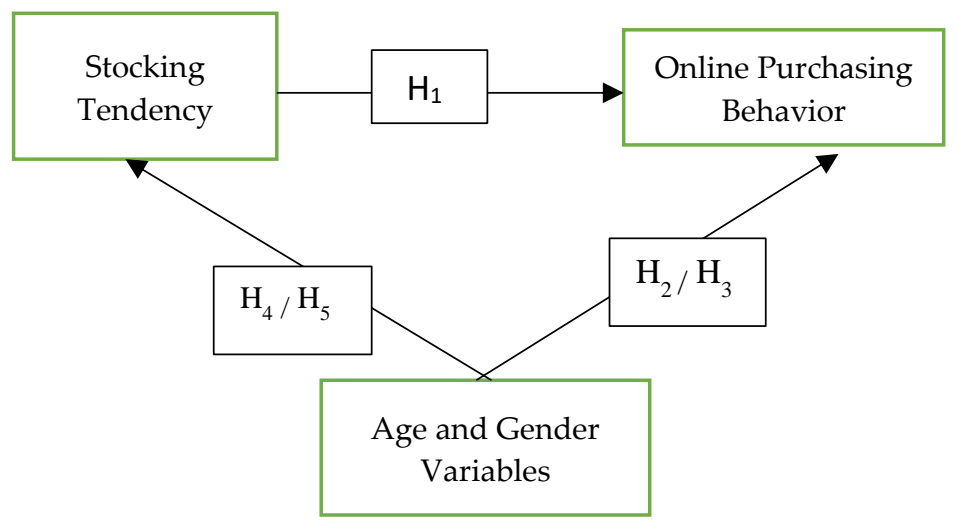

Figure 2. Relational model of the research

During the epidemic, the stocking tendency of the consumers positively affects the online buying behavior. According to the survey of consumers, respectively, during the period of the outbreak in Turkey, most tea / coffee, home cleaning products, has reached the conclusion that buy pasta and dried beans. When the stocking tendencies of consumers are examined during the epidemic period, it is seen that women tend to stock more than men. It has 
been observed that the trend of stocking does not make any difference according to age. In addition, it was found that gender did not make a difference in online buying behavior, while young consumers (18-31 years) made more online purchases compared to older consumers.

Even if the risk of epidemic disappears completely, it is possible to talk about consumer behavior that will change permanently. Consumers stated that they would be careful not to enter crowded environments and to leave the house unless they have to. Based on these answers, in cleaning products; It can be suggested to emphasize the words 'extra protective, increased hygiene, purifying, disinfecting'. Companies may be offered to allocate a special time and budget for social media marketing.

When the researches are examined and the results of this research are taken into consideration, it is seen that many consumers are in demand for products that will not deteriorate in the long term (flour, pulses, pasta, etc.) and products with high functional benefits (tuna, dry meat, canned foods with high protein etc.). Therefore, companies may be advised to increase the protein and mineral content of the products they market, and to position their brands as a healthy and functional brand by announcing this change to their consumers. It is among the suggestions that marketing firms develop applications that will enable older consumers to shop online easily.

In future researches, it can be suggested to establish hypotheses in this direction by adding questions about the marital status of the consumers, whether they have children or how many children they have in the demographic variables section. Considering that the time spent by consumers in social media during the Covid19 virus has increased, researches related to their digital consumption can be conducted.

\section{Kaynakça / References}

Aksoy, R. (2019). Tüketicilerin web siteleri tasarımına bakış açısının online satın alma niyeti üzerine etkisi. Yüksek Lisans Tezi. Gazi Üniversitesi, Ankara.

Aktan C. ve Şen, H. (2001). Ekonomik kriz: nedenler ve çözüm önerileri, Yeni Türkiye Dergisi, Ekonomik Kriz Özel Sayısı, 7 (42). 1225-1230.

Arslan, A. (2009). Kriz yönetiminde liderlik. Akademik Bakış Uluslararası Hakemli Sosyal Bilimler E-Dergisi, 18, 179-190.

Babin, B. J., Darden, W.R. ve Griffin, M. (1994).Work and/or fun: measuring hedonic and utilitarian shopping value. Journal of Consumer Research, 20(4), 644- 656. 
Coronavirus These Countries Restrict Travel To China (2020) Bloomberg News, coronavirus these countries restrict travel to china 27.03.2020 tarihinde https://www.bloomberg.com/news/articles/2020-02-02/coronavirusthese-countries-airlines-restrict-travel-to-china adresinden erişilmiştir.

Büyüköztürk, Ş. (2005). Anket Geliştirme. Türk Ĕ̆itim Bilimleri Dergisi, 3 (2), 133-148.

Cavallo, A., E. Cavallo ve R. Rigobon (2014). Prices and supply disruptions during natural disasters. Review of Income and Wealth, 60(S2), 449-471.

Criteo (2020). 5 ways the coronavirus is affecting consumer behavior.30.03.2020 tarihinde https://www.criteo.com/insights/coronavirusconsumer-behavior/ adresinden erişilmiştir.

Demirali, Y. E. (1995). Ölçeklerde geçerlik ve güvenirlik. M.Ü. Atatürk Eğitim Fakültesi Ĕ̈itim Bilimleri Dergisi, 7, 125-148.

Doğrul, Ü. (2012). Elektronik alışveriş davranışında faydacı ve hedonik güdülerin etkisi. Sosyal ve Beşeri Bilimler Dergisi, 4(1), 321-331.

Durmuş, B., Yurtkoru,S. ve Çinko,M. (2013). Sosyal bilimlerde SPPS'le veri analizi 5.Baskı. İstanbul: Beta Basım Yayın Dağıtım A.Ş.

Dutton, J. E. (1986). The processing of crisis and non-crisis strategic issues. Journal of Management Studies, 23(5),501-517.

Ekinci, M. (2019). Dijital pazarlama çalışmalarmın tüketicinin online satın alma kararna etkileri üzerine bir araştırma. Yüksek Lisans Tezi. Galatasaray Üniversitesi, İstanbul.

Erdil, M. (2014). Online tüketici yorumlarının tüketici satın alma davranışı üzerine etkileri. Doktora Tezi. İstanbul Üniversitesi, İstanbul.

Floyd, M. F., Gibson, H., Pennington-Gray, L., ve Thapa, B. (2004). The effect of risk perceptions on intentions to travel in the aftermath of September 11, 2001. Journal of Travel and Tourism Marketing, 15(2-3), 19-38.

Frank, B., ve Schvaneveldt, S. J. (2016). Understanding consumer reactions to product contamination risks after national disasters: The roles of knowledge, experience, and information sources. Journal of Retailing and Consumer Services, 28, 199-208.

Guion, D. T., Scammon, D. L., ve Borders, A. L. (2007). Weathering the storm: A social marketing perspective on disaster preparedness and response with lessons from Hurricane Katrina. Journal of Public Policy ve Marketing, 26(1), 20-32.

Gülşen, İ ve Özdemir Ş., (2018). Perakendecilikte teknolojik yenilikler ve uygulamalar. Beta Dergisi. 4(1).

Gürbüz, S., ve Şahin, F. (2017). Sosyal bilimlerde araştırma yöntemleri Felsefe-Yöntem-Analiz. 4. Baskı, Seçkin Yayınevi. 
Harrison Mcknight, D., Choudhury, V. ve Kacmar, C. (2002). The impact of initial consumer trust on intentions to transact with a web site: A trust building model. The Journal of Strategic Information Systems, 11(3-4), 297-323.

$\mathrm{Hu}$, X., H. Gurnani ve L. Wang. (2013). Managing risk of supply disruptions: incentives for capacity restoration. Production and Operations Management, 22(1), 137-150.

İçişleri Bakanlığı (2020). 65 yas ve ustu ile kronik rahatsizligi olanlara sokaga cikma yasagi ek genelgesi. 29.03.2020 tarihinde https://www.icisleri.gov.tr/65-yas-ve-ustu-ile-kronik-rahatsizligi-olanlara-sokaga-cikma-yasagi-ek-genelgesi adresinden erişilmiştir.

İnal, S. (2016). Middle east respiratory syndrome-coronavirus (mers-cov) enfeksiyonu: Ortadoğu solunum yetmezliği sendromu-koronavirüs enfeksiyonu. Okmeydanı Ttp Dergisi, 32(Ek sayı), 37-45.

İpsos, Hane Tüketim Paneli (2020). 28.03.2020 tarihinde https://www.ipsos.com/tr-tr. adresinden erişilmiştir.

İpsos, Tüketim Ürünleri Harcaması Raporu (2020). 30.03 .2020 tarihinde https://www.ipsos.com/tr-tr/koronavirus-hane-ici-hizli-tuketim-urunleriharcamalarina-nasil-etki-ediyor adresinden erişilmiştir.

İzgi, B. B.ve Şahin, İ. (2013). Elektronik perakende sektörü ve internet alişverişi tüketici davranışı: Türkiye örneği. Muğla Sıtkı Koçman Üniversitesi Iktisadi ve Idari Bilimler Fakültesi Ekonomi Ve Yönetim Araştirmalari Dergisi, 2(1), 9-27.

Jamal, T. ve Budke, C. (2020). Tourism in a world with pandemics: local-global responsibility and action. Journal of Tourism Futures, Vol. ahead-of-print

Karakoyun, F. ve Kavak, T. (2008). Web anketin yararları ve bir uygulama örneği olarak fizik tutum ölçeğine uygulanmas. D.Ü.Ziya Gökalp Ĕğitim Fakültesi Dergisi. 11, 129-141.

Kennett-Hensel, P. A., Sneath, J. Z., ve Lacey, R. (2012). Liminality and consumption in the aftermath of a natural disaster. Journal of Consumer Marketing, 29(1), 5263

Khan, S. ve Rizvi, A. (2012). Factors influencing the consumers' intention to shop online. Skyline Business journal, 7(1), 28-40.

King, D. ve Devasagayam, R. (2017). An endowment, commodity, and prospect theory perspective on consumer hoarding behavior. Journal of Business Theory and Practice. 5(2). www.scholink.org/ojs/index.php/jbtp 77

Liu, C. ve Arnett, K. P. (2000). Exploring the factors associated with web site success in the context of electronic commerce. Information and Management, 38(1), 2333. 
Mckinsey (2020). 30.03.2020 tarihinde https://www.mckinsey.com/business-functions/risk/our-insights/covid-19-implications-for-business adresinden erişilmiştir.

Murray, K. B., Di Muro, F., Finn, A., ve Leszczyc, P. P. (2010). The Effect of Weather on Consumer Spending. Journal of Retailing and Consumer Services, 17(6), 512520.

Müftüoğlu, D. (2004). Ekonomik kriz dönemlerinde anlık alı̧veriş yapan tüketicileri planlı tüketicilerden ayıran özellikleri belirlemeye yönelik bir uygulama. Yüksek Lisans Tezi. Çukurova Üniversitesi, Adana.

Novelli, M., Burgess, L. G., Jones, A., ve Ritchie, B. W. (2018). No Ebola...still doomed, the Ebola-induced tourism crisis. Annals of Tourism Research, 70, 76-87.

Nytimes (2020). 29.03.2020 tarihinde https://www.nytimes.com/2020/02/06/world/asia/chinese-doctor-Li-Wenliang-coronavirus.html. adresinden erişilmiştir.

Özden, A. T. (2007). Etnosentrik eğilimin tüketicilerin satın alma davranışına etkisi: Doğu Anadolu ve Karadeniz bölgeleri üzerine karşlaştırmalı analiz. Doktora Tezi. Başkent Üniversitesi, Ankara.

Özgüven, N. (2011). Tüketicilerin online alışverişe karşı tutumları ile demografik özellikleri arasındaki ilişkinin analizi. KMÜ Sosyal ve Ekonomik Araştırmalar Dergisi 13 (21), 47-54

Page, S., Song, H., ve Wu, D. C. (2012). Assessing the impacts of the global economic crisis and swine flu on inbound tourism demand in the United Kingdom. Journal of Travel Research, 51(2), 142-153.

Saygilı M. (2014). Faydacı ve hazcı alı̧veriş motivasyonlarınn online satı alma niyeti üzerine etkisi. Yüksek Lisans Tezi. Sakarya Üniversitesi, Sakarya.

Sağlık Bakanlı̆̆ (2020). 04.04.2020 tarihinde https://covid19.saglik.gov.tr/ adresinden erişilmiştir.

Silva, J., Pınho, J.C., Soares, A. ve Sá, E.(2019). Antecedents of onlıne purchase intention and behaviour: uncovering unobserved heterogeneity. Journal of Business Economics and Management 20(1), 131-148.

Silvera, D.H., Lavack, A.M. ve Kropp, F. (2008). Impulse buying: the role of affect, social influence, and subjective wellbeing. Journal of Consumer Marketing, 25(1), 23-33.

Statista, Bozulabilir Yiyecek Tüketim Raporu (2020). 28.03.2020 tarihinde https://www.statista.com/chart/21109/sales-growth-of-non-perishablefood-items-in-the-us/. adresinden erişilmiştir. 
Statista, Pandemi Sonrası Alışveriş Raporu (2020). 30.03 .2020 tarihinde https://www.statista.com/statistics/1102863/vietnam-impact-on-shoppingafter-covid-19-outbreak/. adresinden erişilmiştir.

Statista, Tüketim Raporu (2020). 28.03.2020 tarihinde https://www.statista.com/statistics/1108088/products-and-services-people-spend-more-ondue-to-the-covid-19-pandemic/. adresinden erişilmiştir. Su, S., Wong, G. ve Shi, W. (2016). Epidemiology, combination and pathogenesis of Coronavirus. Journal of Trends Microbiol, 24, 490-502.

Swinyard, W.R. ve Smith, S.M. (2003). Why people (don't) shop online: A lifestyle study of the internet consumer. Psychology E Marketing, 20 (7), 567-598.

Udo, G. J. (2001). Privacy and security concerns as major barriers for e-commerce: a survey study. Information Management and Computer Security, 9(4), 165-174.

Uğraş, T., Reis, Z.A. ve Kartal, E. (2011). Bir online anket sistemi için yol haritası. XIII. Akademik Bilişim Konferansı. 2-4 Şubat 2011. 371-378. İnönü Üniversitesi, Malatya, Türkiye

Ulutaş, S. (2010). Kriz yönetimi ve dönüşümcü liderlik. Yüksek Lisans Tezi. Dokuz Eylül Üniversitesi, İzmir.

WHO (Dünya Sağlık Örgütü). Sars Raporu. 30.03.2020 tarihinde https:/www.who.int/csr/sars/country/table2004_04_21/en/. adresinden erişilmiştir.

WHO (Dünya Sağlık Örgütü). Pandemi Raporu 27.03.2020 tarihinde https://www.who.int/emergencies/diseases/novel-coronavirus-2019. adresinden erişilmiştir.

Worldometers (2020). 30.03.2020 tarihinde https:/www.worldometers.info/coronavirus/ . adresinden erişilmiştir.

\section{Kaynakça Bilgisi / Citation Information}

İnce, M. ve Tor-Kadıŏlu, C. (2020). Tüketicilerin Covid19 (Korona) virüsüyle artan stoklama isteğinin online satın alma davranışına etkisi. OPUS-Uluslararası Toplum Araştırmaları Dergisi, 16(29), 1875-1906. DOI: 10.26466/opus.716041 